\title{
Prediction of spontaneous coronary reperfusion in myocardial infarction
}

\author{
Freek W.A. Verheugt, Frans C. Visser, Ernst E. van der Wall, Machiel J. van \\ Eenige, Jan C.J. Res and Jan P. Roos
}

Department of Cardiology, Free University Hospital, Amsterdam, The Netherlands

\begin{abstract}
Summary: To investigate the possibility of predicting the occurrence of spontaneous coronary reperfusion in acute myocardial infarction we studied 91 patients in a randomized trial on the clinical efficacy of intracoronary streptokinase compared to conventional treatment. Of the $\mathbf{4 6}$ patients treated conventionally 40 had catheterization 6 weeks after the infarction. Spontaneous coronary reperfusion was found in 19 patients (48\%). The time to peak CK-MB in these patients was considerably longer than in patients with streptokinase-induced coronary reperfusion and similar to the time in patients without spontaneous coronary reperfusion. Spontaneous coronary reperfusion was associated with a relative improvement of radionuclide ejection fraction from day 1 to day 14 after admission. There was no difference in the occurrence of ventricular arrhythmia or recurrent ischaemic events between the patients with and those without spontaneous coronary reperfusion.

Thus, spontaneous coronary reperfusion is not uncommon in traditionally treated myocardial infarction, but its occurrence cannot be predicted by enzymatic or clinical parameters.
\end{abstract}

Introduction

In most cases of acute myocardial transmural infarction proximal thrombotic occlusion of a major coronary artery is found (DeWood et al., 1980). Intracoronary or intravenous thrombolytic therapy has been shown to be effective in reperfusing occluded coronary arteries (Kahja et al., 1983; Kennedy et al., 1983; Anderson et al., 1984; Rentrop et al., 1983; 1984; Simoons et al., 1985). Spontaneous coronary reperfusion has been observed in about $10 \%$ of patients with acute transmural myocardial infarction undergoing coronary angiography within 6 hours after onset of symptoms (Smalling et al., 1983; Rentrop et al., 1984; Anderson et al., 1984; Simoons et al., 1985). On coronary angiography in the chronic phase of myocardial infarction spontaneous coronary reperfusion is seen in up to $40 \%$ of cases (DeFeyter et al., 1983; Verheugt et al., 1984).

As there are indications that spontaneous coronary reperfusion leads to preservation of left ventricular function (DeFeyter et al., 1983) it would be of interest to be able to predict spontaneous coronary reperfusion.

Presented in part on the 57th Scientific Sessions of The American Heart Association, Miami Beach, November 12-15, 1984

Correspondence: F.W.A. Verheugt, M.D.

Accepted: 16 June 1986
Streptokinase-induced coronary reperfusion in acute myocardial infarction results in rapid myocardial enzyme washout (Blanke et al., 1984). Some investigators have used this laboratory finding as an indicator of spontaneous coronary reperfusion without angiographic proof afterwards (Ong et al., 1983).

The purpose of this study was to assess the value of clinical and laboratory parameters in the prediction of spontaneous coronary reperfusion in acute myocardial infarction. Therefore we studied a well documented group of patients with acute myocardial infarction undergoing standard treatment and compared it with a group of patients who had intracoronary streptokinase intervention during the acute stage of their infarction.

\section{Patients and methods}

Ninety-one patients were randomized to study the effect of intracoronary streptokinase in comparison with conventional treatment. The patients participated in a larger randomized trial, of which the methods and results are published in detail elsewhere (Simoons et al., 1985). Patients allocated to conventional treatment were treated with subcutaneous heparin $10,000 \mathrm{U}$ per 24 hours and simultaneously with coumadin. When the partial thromboplastin 
time exceeded 120 seconds, heparin was discontinued. At discharge, usually within 14 days after admission, coumadin was discontinued as well.

In all patients blood samples for routine analysis were taken at $0,3,6,12,18,24,36$ and 48 hours after randomization. Radionuclide ventriculography was performed in all patients within 48 hours after randomization and at discharge in the surviving patients. Within 6 weeks after discharge coronary angiography and left ventricular angiography was planned in all patients.

Forty six patients were allocated to conventional and 45 patients to intracoronary streptokinase treatment.

Of the 46 patients allocated to conventional treatment 6 did not undergo angiography at 6 weeks because of death in 3 and refusal in 3 . The remaining 40 patients were studied for the prediction of spontaneous coronary reperfusion in acute myocardial infarction (group A). Of the 45 patients allocated to streptokinase treatment 9 did not undergo acute coronary angiography because of refusal (6 patients), peripheral vascular occlusion (2 patients) and longstanding cardiac massage after randomization in one patient. Of the 36 remaining patients $9(25 \%)$ had an unsuccessful fibrinolytic procedure. Together with the remaining 27 patients they were used as the reference group for the presence or absence of acute coronary reperfusion (group B).

\section{Results}

In group A spontaneous coronary reperfusion was observed in 19 patients $(49 \%)$. The relation between time to peak CK-MB and the occurrence of coronary reperfusion in groups A and $B$ is given in Table $I$. Streptokinase-induced reperfusion results in an early enzyme peak, whilst spontaneous coronary reperfusion does not. Unsuccessful streptokinase intervention shows a similar late enzyme peak.

Changes in radionuclide left ventricular ejection fraction in group A are presented in Table II. Spontan- eous coronary reperfusion seems to be correlated with an improvement of left ventricular function.

Table III shows the occurrence of early $(<48$ hours after admission, late ( $>48$ hours after admission) ventricular fibrillation or sustained ventricular tachycardia and recurrent ischaemic events (angina or myocardial infarction in the same region) before angiography at 6 weeks in group A. There are no significant differences in the occurrence of ventricular arrhythmia or recurrent ischaemia between patients with and those without an occluded infarct related coronary artery.

\section{Discussion}

Spontaneous coronary reperfusion is not an uncommon finding in myocardial infarction. We found an incidence of $48 \%$. In patients with spontaneous coronary reperfusion left ventricular function is better (DeFeyter et al., 1983), though the mechanism of this phenomenon is unclear. It would be useful to be able to predict the occurrence of spontaneous reperfusion.

In this study we confirmed the observation of better left ventricular function in patients showing an open infarct related vessel at late angiography. However, neither clinical nor laboratory data during the evolution of the infarction reflect the presence or absence o $\$$ spontaneous coronary reperfusion. Therefore, exe treme caution is necessary in the interpretation studies dealing with reperfusion in acute myocardiaf infarction without coronary angiography afterwards (Ong et al., 1983).

We used streptokinase-induced early reperfusion as a reference for the laboratory parameters of coronary reperfusion. It is possible that intracoronary streptokinase by itself could alter myocardial enzyme washout. However, we found that patients with an unsuccessful intervention show a late peak, as observed previously (Schwarz et al., 1984). So, early enzyme peaks are reperfusion dependent and not drug dependent.

These data indicate that spontaneous coronary reperfusion seems to occur rather late in the course of

Table I Myocardial enzyme release pattern in both groups

\begin{tabular}{lcccc}
\hline & Group A & Group B & No \\
& $\begin{array}{c}\text { Spontaneous } \\
\text { reperfusion }\end{array}$ & $\begin{array}{c}\text { Npontaneous } \\
\text { reperfusion }\end{array}$ & $\begin{array}{c}\text { Streptokinase- } \\
\text { induced } \\
\text { reperfusion }\end{array}$ & $\begin{array}{c}\text { streptokinase- } \\
\text { induced } \\
\text { reperfusion }\end{array}$ \\
\hline $\begin{array}{l}\text { Number of patients } \\
\text { Time to peak CK-MB (hours) }\end{array}$ & $17.4 \pm 5.7^{*}$ & $18.2 \pm 5.4$ & $8.7 \pm 3.1$ & $15.6 \pm 3.2$ \\
\hline
\end{tabular}

${ }^{*} P<0.0001$ vs streptokinase-induced reperfusion. 
Table II Radionuclide left ventricular ejection fraction in group $\mathbf{A}$

\begin{tabular}{lcc}
\hline & $\begin{array}{c}\text { Spontaneous } \\
\text { reperfusion }\end{array}$ & $\begin{array}{c}\text { No } \\
\text { spontaneous } \\
\text { reperfusion }\end{array}$ \\
\hline Number of patients & 19 & 21 \\
LVEF on day 1 & $0.40 \pm 0.12$ & $0.41 \pm 0.09$ \\
LVEF on day 14 & $0.45 \pm 0.11$ & $0.39 \pm 0.12$ \\
$\triangle$ LVEF (\%) & $+15.0 \pm 8.9^{*}$ & $-4.8 \pm 29.4$
\end{tabular}

\footnotetext{
$* P<0.05$

LVEF = left ventricular ejection fraction

$\triangle \mathrm{LVEF}=\frac{\text { LVEF day } 1-\text { LVEF day } 14}{\text { LVEF day } 1}$
}

myocardial infarction without clinical manifestations. If reperfusion occurs late, preservation of left ventricular function becomes less likely. The results of this study do not offer an explanation for the preservation of left ventricular function in relation to a patent infarct-related coronary artery. There must be factors

\section{References}

ANDERSON, J.L., MARSHALL, H.W., ASKIN, J.C., LUTZ, J.R., SORENSEN, S.G., MENLOVE, R.L., YANOWITZ, F.G. \& HAGAN, A.D. (1984). A randomized trial of intravenous and intracoronary streptokinase in patients with acute myocardial infarction. Circulation, 70, 606.

BLANKE, H., VON HARDENBERG, D., COHEN, M., KAISER, H., KARSCH, K.R., HOLT, J., SMITH, H. \& RENTROP, P. (1984). Patterns of creatine kinase release during acute myocardial infarction after nonsurgical reperfusion: comparison with conventional treatment and correlation with infarct size. Journal of the American College of Cardiology, 3, 675.

DE FEYTER, P.J., VAN EENIGE, M.J., VAN DER WALL, E.E., BEZEMER, P.D., VAN ENGELEN, C.L.J., FUNKE KUEPPER, A.J., KERNKAMP, H.J.J., VISSER, F.C. \& ROOS, J.P. (1983). Effects of spontaneous and streptokinase-induced recanalization on left ventricular function in acute myocardial infarction. Circulation, 67, 1039.

DEWOOD, M.A., SPORES, J., NOTSKE, R., MOUSER, L.T., BURROUGHS, R., GOLDEN, M.S. \& LANG, T.H. (1980). Prevalence of total coronary occlusion during the early hours, of transmural myocardial infarction. New England Journal of Medicine, 303, 897.

KAHJA, F., WALTON, J.A., BRYMER, J.F., LO, E., OSTERBERGER, L., O'NEILL, W.W., COLFER, H.T., WEISS, R., LEE, T., KURIAN, T., GOLDBERG, A.D., PITT, B. \& GOLDSTEIN, S. (1983). Intracoronary fibrinolytic therapy in acute myocardial infarction. Report of a randomized prospective trial. New England Journal of Medicine, 308, 1305.

KENNEDY, J.W., RITCHIE, J.L., DAVIS, K.B. \& FRITZ, J.K. (1983). Western Washington randomized trial of in-
Table III Clinical events in group A

\begin{tabular}{lcc}
\hline & $\begin{array}{c}\text { Spontaneous } \\
\text { reperfusion }\end{array}$ & $\begin{array}{c}\text { No } \\
\text { spontaneous } \\
\text { reperfusion }\end{array}$ \\
\hline Number of patients & 19 & 21 \\
Early VT/VF & $6(33 \%)$ & $11(52 \%)$ \\
Late VT/VF & $2(11 \%)$ & $2(10 \%)$ \\
Recurrent angina & $2(11 \%)$ & $1(5 \%)$ \\
Recurrent infarction & $1(5 \%)$ & $1(5 \%)$
\end{tabular}

$\mathrm{VT} / \mathrm{VF}=$ Ventricular tachycardia/fibrillation.

other than reperfusion alone, that lead to salvage of myocardium in the course of myocardial infarction. Moreover these factors cannot be identified by laboratory or clinical parameters during the acute phase of myocardial infarction.

tracoronary streptokinase in acute myocardial infarction. New England Journal of Medicine, 309, 1477.

ONG, L., REISER, P., COROMILAS, J., SCHERR, L. \& MORRISON, J. (1983). Left ventricular function and rapid release of creatine kinase MB in acute myocardial infarction: evidence for spontaneous reperfusion. New England Journal of Medicine, 309, 1.

RENTROP, P., SMITH, H., PAINTER, L. \& HOLT, J. (1983). Changes in left ventricular ejection fraction after intracoronary thrombolytic therapy. Results of the Registry of the European Society of Cardiology. Circulation, 68 (Suppl 1), 55.

RENTROP, K.P., FEIT, F., BLANKE, H., STECY, P., SCHNEIDER, S., REY, M., HOROWITZ, S., GOLDMAN, M., KARSCH, K., MEILMAN, H., COHEN, M., SIEGEL, S., SANGER, J., SLATER, J., GORLIN, R., FOX, A., FAGERSTROM, R. \& CALHOUN, W.F. (1984). Effects of intracoronary streptokinase and nitroglycerin infusion on coronary angiographic patterns and mortality in patients with acute myocardial infarction. New England Journal of Medicine, 311, 1457.

SCHWARZ, F., FAURE, A., KATUS, H., VON OLSHAUSEN, K., HOFFMANN, M., SCHULER, G., MANTHEY, J. \& KUEBLER, W. (1984). Intracoronary thrombolysis in acute myocardial infarction: an attempt to quantitate its effect by comparison of enzymatic estimate of myocardial necrosis with left ventricular ejection fraction. American Journal of Cardiology, 51, 1572.

SIMOONS, M.L., VAN DEN BRAND, M., DE ZWAAN, C., VERHEUGT, F.W.A., REMME, W.J., SERRUYS, P.W., BAER, F., RES, J., KRAUSS, X.H., VERMEER, F. \& LUBSEN, 
J. (1985). Improved survival after early thrombolysis in acute myocardial infarction. A randomized trial by the Interuniversity Cardiology Institute in The Netherlands. Lancet, ii, 578.

SMALLING, R.W., FUENTES, F., MATTHEWS, M.W., FREUND, G.C., HICKS, C.H., REDUTO, L.A., WALKER, W.E., STERLING, R.P. \& GOULD, K.L. (1983). Sustained improvement in left ventricular function and mortality by intracoronary streptokinase administration during evolving myocardial infarction. Circulation, 68,131.

VERHEUGT, F.W.A., VAN DER WALL, E.E., RES, J.C.J. \& $ᄃ$ ROOS, J.P. (1984). Spontaneous coronary reperfusion in myocardial infarction: prediction and occurrence. Circulation, 70 (Suppl 2), 331. 